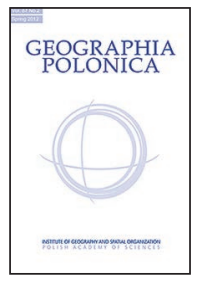

\title{
SPATIAL DIVERSITY OF CLOUD-TO-GROUND LIGHTNING FLASHES IN THE KUJAWSKO-POMORSKIE VOIVODESHIP (POLAND), 2002-2019
}

\author{
Sławomir Sulik ${ }^{1}$ (D) Marek Kejna ${ }^{2}$ (D) \\ ${ }^{1}$ Faculty of Earth Sciences and Spatial Management \\ Nicolaus Copernicus University \\ Lwowska 1, 87-100 Toruń: Poland \\ e-mail: sulik@umk.pl \\ ${ }^{2}$ Faculty of Earth Sciences and Spatial Management, Department of Meteorology and Climatology \\ Nicolaus Copernicus University \\ Lwowska 1, 87-100 Toruń: Poland \\ e-mail: marek.kejna@umk.pl
}

\begin{abstract}
This research focuses on the spatial diversity of cloud-to-ground (CG) flashes in the Kujawsko-Pomorskie voivodeship (Poland) based on data from the PERUN lightning detection system, 2002-2019. The storm season usually lasts from May to September, with July having the highest number of thunderstorms days and flashes. Thunderstorms most often occur in the afternoon. A generated grid of $5 \times 5-\mathrm{km}$ cells was used to characterise the variables related to CG flashes. In the analysed period 432,925 CG flashes were detected in the voivodeship $\left(24,051\right.$ flashes year $\left.{ }^{-1}\right)$. The highest electrical activity was found in the south-eastern part of the province. In grids with a large water surface, the number of CG flashes was small and increased with distance from the Vistula River. The distribution of atmospheric discharges in major cities of the region (Bydgoszcz, Torun, Włocławek and Grudziqqdz) was random. Years with greater electrical storm activity (27,614 discharges in 2017) are interspersed with calmer years (5000-7000 discharges). There were found an upward trend in lightning discharges (of 1681 discharges year ${ }^{-1}$ ) during period 2002-2019. To develop maps specifying the number of thunderstorm days, a $1 \times 1-\mathrm{km}$ grid cell was used with a $15-\mathrm{km}$ radius buffer from the bin centre. The annual number of thunderstorm days in the voivodeship fluctuates from 27 to 41 days and increases from north-west to south-east. Consecutive days with a thunderstorm, the most common runs are of three days in a row with a storm. The number of thunderstorm days shows an increasing trend $\left(0.82\right.$ days year $\left.{ }^{-1}\right)$. This trend is related to the increase in air temperature in the storm season (Apr-Sep) reaching $\left(0.04^{\circ} \mathrm{C}_{\text {year }}{ }^{-1}\right)$.
\end{abstract}

\section{Key words}

cloud-to-ground lightning - thunderstorm days - climate change - Kujawsko-Pomorskie voivodeship • Poland 


\section{Introduction}

Thunderstorms pose a threat to human life, health and property. The danger is generated not only by severe wind, heavy rainfall and hail but also by cloud-to-ground (CG) lightning flashes. According to reports of Statistics Poland (GUS, 2020), on average 16 people die in Poland every year as a result of lightning. According to the European Severe Weather Database, in the period 2012-2014 in Poland there were over 100 storm cell transitions with high electrical activity, which killed 17 people (Taszarek et al., 2015).

Previous studies on lightning climatologies have been made very difficult by the lack of an appropriate system that would allow detection of lightning. Thunderstorm days were defined as the occurrence of an atmospheric discharge spotted by an observer, most often at a synoptic station. The results of years of observation made it possible to carry out climatological studies of storm phenomena, e.g. research by Bielec-Bqkowska (2013) in Poland. However, these observations did not allow the spatial differentiation of lightning discharges to be determined. The currently used detection methods enable detection of discharges and their division by type and charge. This makes it possible to calculate the number of discharges on a given day, with exact locations.

A number of studies have been published concerning various European countries. Based on data from the Austrian detection system, alternative to the Polish equivalent, Schulz et al. (2005) made a study covering 1992-2001 that proved that storms occur most often in the period from May to August, reaching the highest frequency in the southern part of Austria, where meteorological and topographic conditions are optimal for creating storms. In the study, the authors adopted a $1 \times 1-k m$ grid as the primary field. They found that on average there are 4 CG flashes $\mathrm{km}^{-2} \cdot \mathrm{yr}^{-1}$. The same grid cell was also used in research for Germany and the surrounding area, but Wapler (2013) received as many as 30 discharges per square kilometre. Similar studies were conducted in the Czech Republic using 20×20-km grids, this time with average discharge values in the range of 1-3 flashes $\mathrm{km}^{-2} \cdot \mathrm{yr}^{-1}$ (Novák \& Kyznarová, 2011).

Research in Portugal has shown the occurrence of a storm season from May to September with a peak period from 16 to 18 UTC (Santos et al., 2012). In Spain, Soriano et al. (2005) analysed ground discharges for fields with dimensions of $0.2 \times 0.2^{\circ}$. The team showed a relationship between lightning and local topography and atmospheric circulation with a maximum of occurrence in the Pyrenees and a minimum around the coast of Catalonia (2 discharges $\mathrm{yr}^{-1}$ ). In Italy, using fields with dimensions $0.1 \times 0.1^{\circ}$ Biron (2009) decided to use a $10 \times 10-\mathrm{km}$ grid field using the Italian detection system (LAMPINET). The highest frequencies of discharges in the period 2005-2007 were recorded in the area of Lake Como, Sardinia, the bay of Trieste and the central Apennines.

In northern Europe, in Sweden, research was conducted for the years 2002-11 for fields with dimensions identical to those of Spain, and the existence of a storm season usually lasting from June to August was confirmed. Work on Finland was combined with research for the United States and was carried out by the team of Mäkelä et al. (2011) with a $20 \times 20-\mathrm{km}$ field, while Enno (2011) performed a study on Estonia for the period 2005-09 with a $10 \times 10-\mathrm{km}$ grid field.

The latest research, from 2019, covering the area of Europe (including Poland) has shown and confirmed the peak of storm activity in July and August. There was also an increase in thunderstorm days, especially in the Alps, and in central, southeastern and eastern Europe (Taszarek et al., 2019). To explain the conditions of storm formation and discharges, the authors of that publication used meteorological data obtained from vertical atmosphere surveys, observations from synoptic stations, data on discharges from ZEUS and EUCLID and reports on weather hazards. The study 
describes annual storm cycles with days with a thunderstorm and their spatial extent.

In Poland, atmospheric discharge studies were made possible by the 2002 introduction and continuous development of the detection system called PERUN. This made it possible to refer to previous synoptic observations regarding, among others, the development of the number of days with a storm for Poland by various authors: Kolendowicz (1996, 2006); Bielec (2000) and Bielec-Bąkowska (2013). Values of thunderstorm days obtained on the basis of visual observations ranged from 15 days in the Baltic Sea region to 33 days in the Carpathian region (Lorenc, 2005; Bielec-Bakowska, 2013). In 2015, a study was developed by authors from the Adam Mickiewicz University in Poznań, where Taszarek et al. (2015) analysed data obtained from the PERUN detection system for Poland for the period 2002-13. To create this analysis, the authors used ground discharges in a $10 \times 10-\mathrm{km}$ reference field. To determine the days with the storm based on the discharges, a $1 \times 1-\mathrm{km}$ field grid was used and a buffer of $17.5 \mathrm{~km}$ was derived from the centre of each field. During a day with a thunderstorm, they reported only on situations in which at least two CG flashes were recorded in the area. The authors found as many as 4,328,892 discharges throughout the entire period studied, with an average of 151 days of storm each year throughout the country. The increase in the number of thunderstorm days from the Baltic Sea towards the south-east was also confirmed. The storm season usually lasts from May to August, with July as the month with the highest frequency of storms. Most of the recorded storms occur during the day, with a maximum around 14:00 and a minimum around 07:00. Importantly, almost $97 \%$ of all discharges had a negative charge and only $3 \%$ positive. By contrast, discharges with a positive charge occurred more often in winter than in summer.

The aim of this article is to provide a spatial analysis of the days with a storm and CG flashes in a smaller area - the
Kujawsko-Pomorskie voivodeship. This Polish province is characterised by slight differences in hypsometry, but a significant diversification in land use (Fig. 1B). There are agricultural areas and extensive forest complexes here. The largest river in Poland, the Vistula River, flows through the voivodeship, which may affect the movement of storms. The analysis examined the variability of lightning throughout the year and day, as well as the variability and trend of the number of days with storms and CG flashes in the analysed period (2002-2019).

\section{Dataset and methodology}

By courtesy of the Instytut Meteorologii i Gospodarki Wodnej (PIB), we were able to build a database of lightning strikes detected by the PERUN network. This network is part of a European lightning detection system SAFIR (Surveillance et d'Alerte Foundre par Interferometrie Radioelectrique). Polish part was launched in 2002 and since that, the system has been nicknamed as PERUN, in reference to the god of thunder and lightning in Slavic mythology (Bodzak, 2006; Czernecki et al., 2016).

The whole lightning measuring network is combined into nine stations located in different regions of Poland: Gorzów Wielkopolski, Częstochowa, Kalisz, Toruń, Sandomierz, Warsaw, Olsztyn, Białystok and Włodawa (Fig. 1A). To distinguish between type of flashes, low-frequency electromagnetic waves was used. Due to this, system detects lightning flashes categorised into (CC) cloudto-cloud, (IC) intra-cloud and (CG) cloudto-ground and it's capable to detect up to 100 strikes per second. The introduction of the new system in Poland creates new opportunities to conduct specific research on the spatial distribution of lightning. The locations of lightning strikes are saved in a lightning listing, along with other parameters such as current charge time, numbers for recognising type of lightning. However, detailed discharge data such as polarity, peak current estimate (kA) 
U
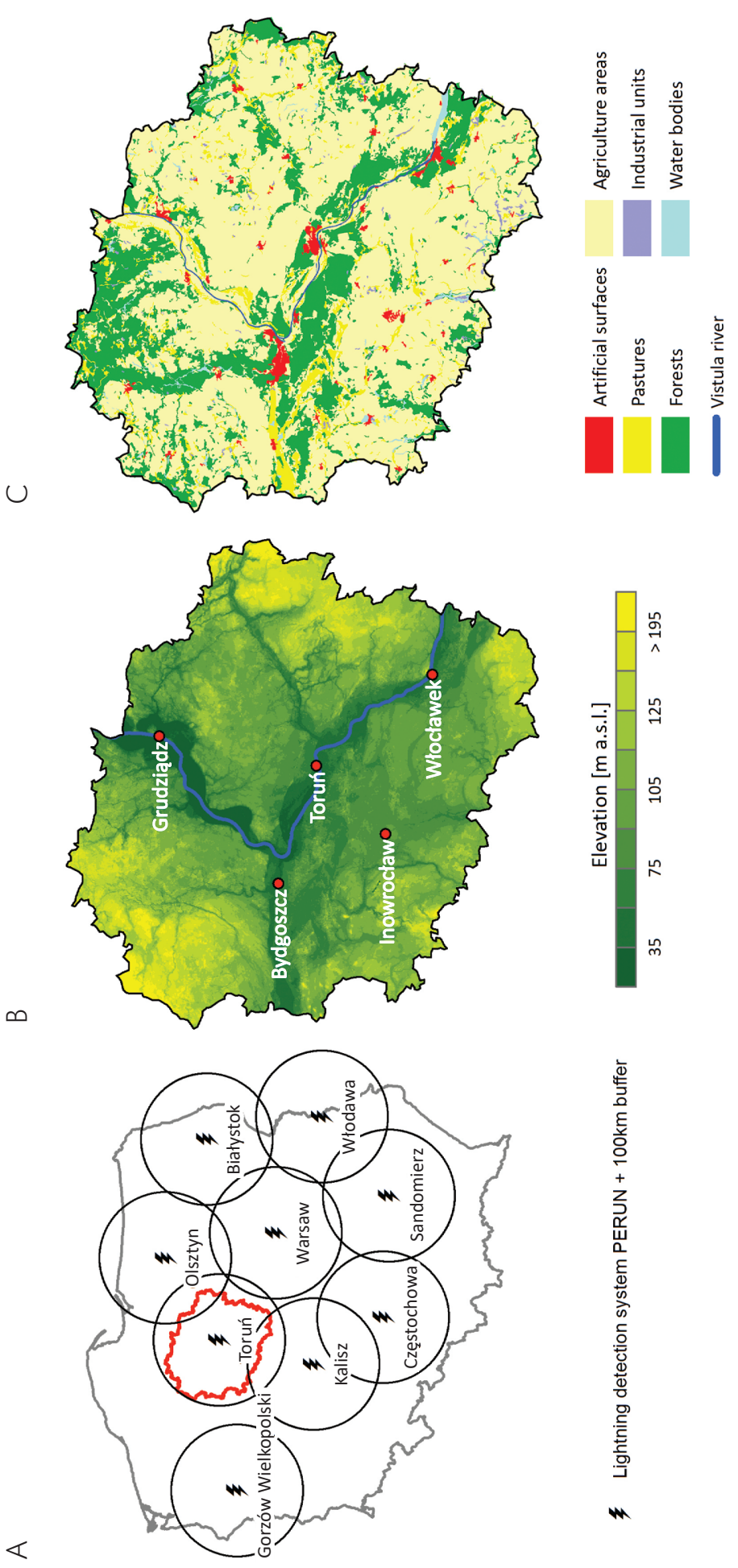

어엄

일

范

$\frac{2}{2} \frac{0}{0}$

응 듬

$\stackrel{\infty}{\sum}$

윤 줄

흥

ज)

: $\frac{0}{ \pm} \stackrel{0}{ \pm}$

늘 己

을 응

क)



ㄷํ으

헌

음을

틀을 응

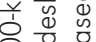

$\therefore$ 응

독 일 을

文 $\frac{0}{v}$

วัำ

등 드

Z $\frac{\dot{v}}{\mathrm{v}}$

뜸 윽

()ㅡㅁ

ᄃ 0

क 인

गे 을

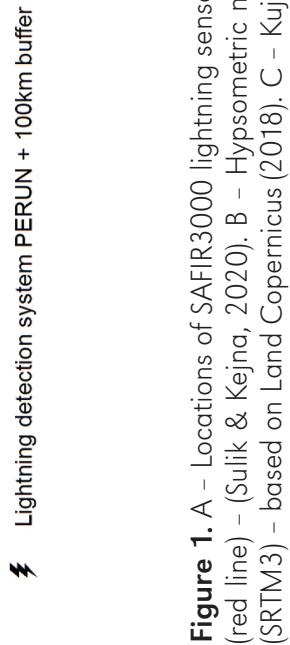


and multiplicity is available only for CG flashes. Due to location errors in detection of CC flashes, only CG flashes were used. Importantly, in the case of ground discharges with a negative charge, these types of discharges tend to "strike" several times during one discharge in one and the same place (multistrokes). Therefore, when processing data, only the first discharge that took place was taken into account.

Taking in account previous studies, it was shown that a reliable accuracy for flash density can be achieved when an average of more than 80 flashes occurs in each grid cell (Diendorfer, 2008). In case of that, we used a $5 \times 5-\mathrm{km}$ grid cell, and we believe it's optimal unit. The calculated data were separated for the administrative area of the Kujawsko-Pomorskie voivodeship. The discharges are geographically located in decimal units (WGS84). Due to the local reference system, it was necessary to convert the coordinates from WGS84 to the Polish metric PUWG (EPSG: 2180) system. The methods are similar as employed in Sulik \& Kejna (2020).

In this study we use a resolution of $5 \times 5-\mathrm{km}$ grid, and we believe that this is the most appropriate for our database and research area. In the area of the Vistula River and cities, we use a $0.5 \times 0.5-\mathrm{km}$ cell grid for smoother analysis. For this purpose, the ESRI ArcMap program generated a grid for the Kujawsko-Pomorskie voivodeship. The average number of CG flashes and their maximum daily values were calculated for each grid annually, providing their number per $\mathrm{km}^{2}$. The same procedure was used to analyse the course of annual discharges for each of the 18 years. As the system locates discharges over time, this type of data was used to plot the course of the daily discharges and these were compiled on charts.

A thunderstorm is a local phenomenon, but an observer can see it from many kilometres away. Often, storm phenomena such as lightning are visible, but they are not experienced in the immediate vicinity of the station. In the climatological literature concerning the area of Poland, it is possible to distinguish various directions of research on storms. It was sometimes difficult to distinguish thunderstorm days based on meteorological observations, due to the horizon being covered or light pollution of the sky, which often occurs at meteorological stations located in cities. Detection systems have overcome these obstacles to determine the number of days with a storm for a selected area, especially for areas where there are no weather stations.

It should be noted that a lightning discharge is visible and audible even from a distance of about 15 kilometres, (Wu et al., 2016) and in an open area, without trees or other elements obscuring visibility, it is visible even from a distance of about $30 \mathrm{~km}$. To refer to earlier standards and guidelines for calculating the occurrence of a storm on a given day, a $1 \times 1-\mathrm{km}$ grid cell was used, from which a buffer was derived in the form of a circle with a radius of $15 \mathrm{~km}$. Similarly, a thunderstorm day was counted when at least one lightning strike (in this case CG) occurred inside this circle. For the statistics on the number of lightning discharges and spatial diversity, only discharges that occurred only within the voivodeship's borders were taken into account.

\section{Results}

\section{Thunderstorm days}

In Poland, there is quite a significant variation in the number of thunderstorm days. Their smallest turnout is recorded in the north of the country within the Baltic Sea coast (15 days), and their number increases to the south-east (33 days in the Tatra Mountains - Bielec-Bakowska, 2013). Therefore, the highest discharge activity occurs in central Poland. This is also the area of conditions most favourable to the formation of tornadoes, as documented in another study by Taszarek et al. (2015).

Taking into account the lightning strikes within $15 \mathrm{~km}, 737$ days with a storm were found in the Kujawsko-Pomorskie voivodeship in the years 2002-2019. The average num- 
ber of days with thunderstorms shows quite a wide variation from 27 to 41 days year ${ }^{-1}$ (Fig. 2). The most days with thunderstorm occurred in the eastern part of the province. However, there were clearly fewer days with a storm in the in large forest complexes (Bory Tucholskie - north-west, and in the Bydgoszcz-Torun Basin - central part of a map).

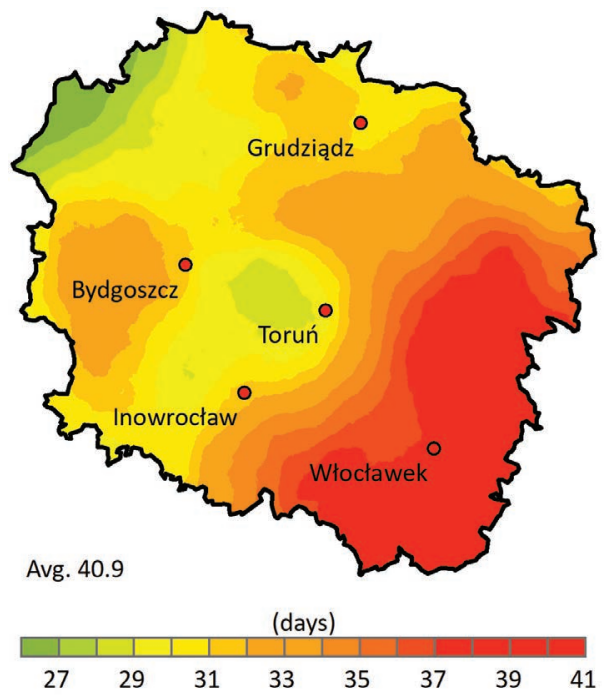

Figure 2. Average number of thunderstorm days in the Kujawsko-Pomorskie voivodeship during the period 2002-2019, based on lightning data from the PERUN network

The results obtained from the remotesensing method differ from previous studies based only on meteorological stations, which for the area of the Kujawsko-Pomorskie voivodeship showed an average of 23 days with a thunderstorm (Bielec-Bakowska, 2013). These differences may be related to significant distances between stations, e.g. only two synoptic stations, in Toruń and Bydgoszcz, operate in the province. Hence, for many regions, the number of days with a storm was interpolated and extrapolated. Remote-sensing data is therefore more reliable.

Analysing individual years it can be seen that, in each of the years there are areas in different parts of the province that have a higher occurrence of storms (Fig. 3).
The south-eastern part of the province dominates as the area where the most thunderstorms occur. This area was also marked in the study of Taszarek et al. (2015) and it is also a small fragment of the extensive storm trail occurring from Mazovia to the regions of the Great Masurian Lakes.

\section{Annual CG lightning flash density}

In the whole period under study (20022019), the PERUN lightning detection system detected over the Kujawsko-Pomorskie voivodeship 432,926 CG discharges, so each year there were on average 24,051 CG lightning flashes. The most atmospheric discharges occurred in the eastern part of voivodeship (Fig. 4A). This area belongs to the storm trail crossing Poland (Taszarek et al., 2015). Furthermore, based on the development of data from the ATD system for the period 2008-2013 (Anderson \& Klugmann, 2014) and from the EUCLID system for 2011 (Pohjola \& Mäkelä, 2013) this area was determined to be characterised by an increased occurrence of CG flashes. The computed map shows an area with a much lower frequency of discharges in the north-western part of the voivodeship, and in the Lower Vistula Valley (the Bydgoszcz-Torun Basin). However, analysing the spatial distribution of storms in the voivodeship, one can also see that weak storm cells expanding over areas such as arable land (low albedo) that are directed by pressure gradients over the Vistula riverbed area often disintegrate due to streams carried by river-cooled air that limits convection. Also, areas located close to the river such as forests or smaller trees have a lower air temperature. Therefore, individual storm cells also often move along the Vistula, without going to the other side, while also strengthening.

The maximum daily discharges amounted to 13.5 flashes $\mathrm{km}^{-2}$ (Fig. 4B). Also, a lot of CG flashes (13 flashes $\mathrm{km}^{-2}$ ) occurred in the north-central area. This means that some storm cells are able to generate more discharges in a given area one day than they 


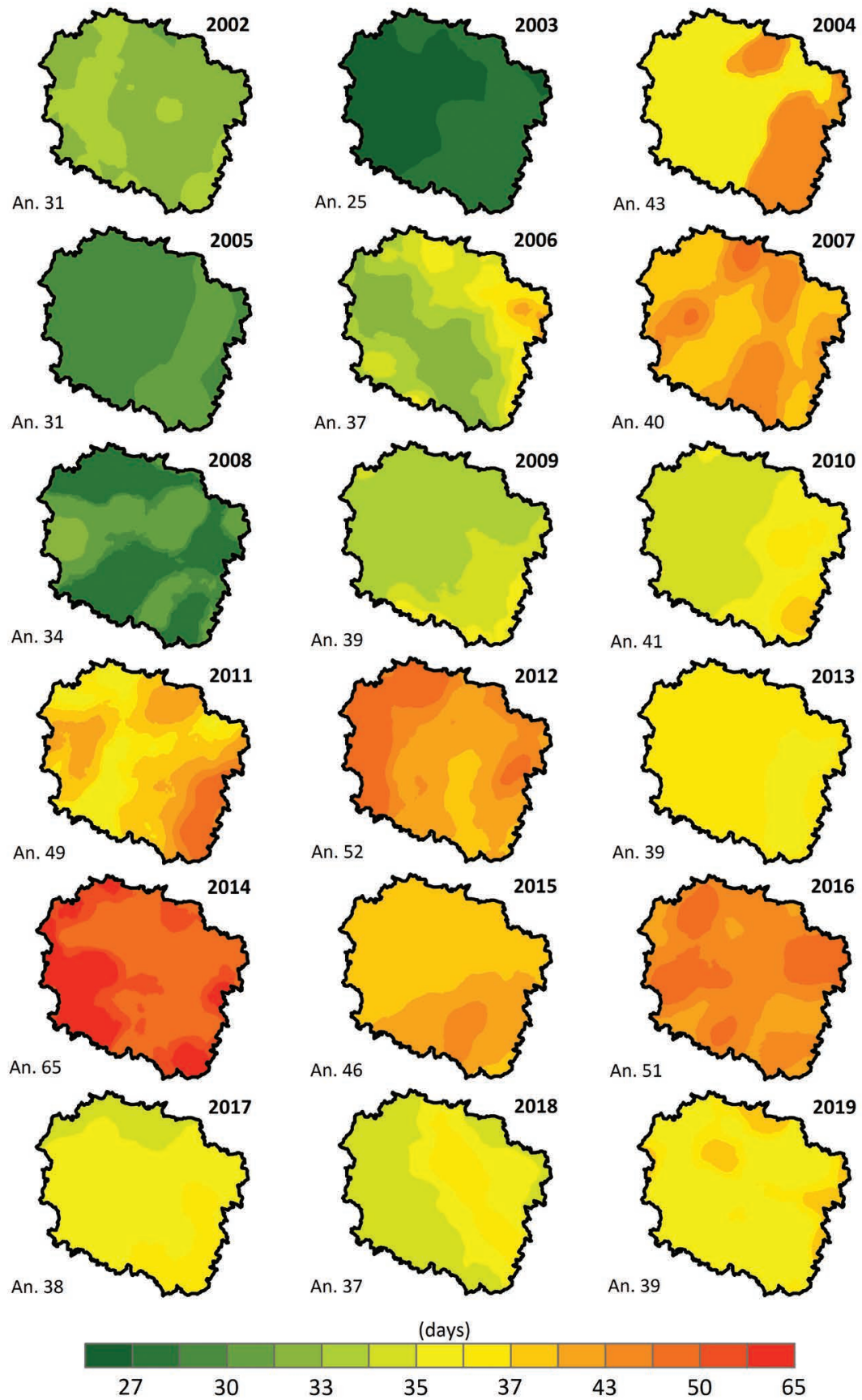

Figure 3. Annual number of thunderstorm days in the Kujawsko-Pomorskie voivodeship during the period 2002-2019, based on lightning data from the PERUN network 

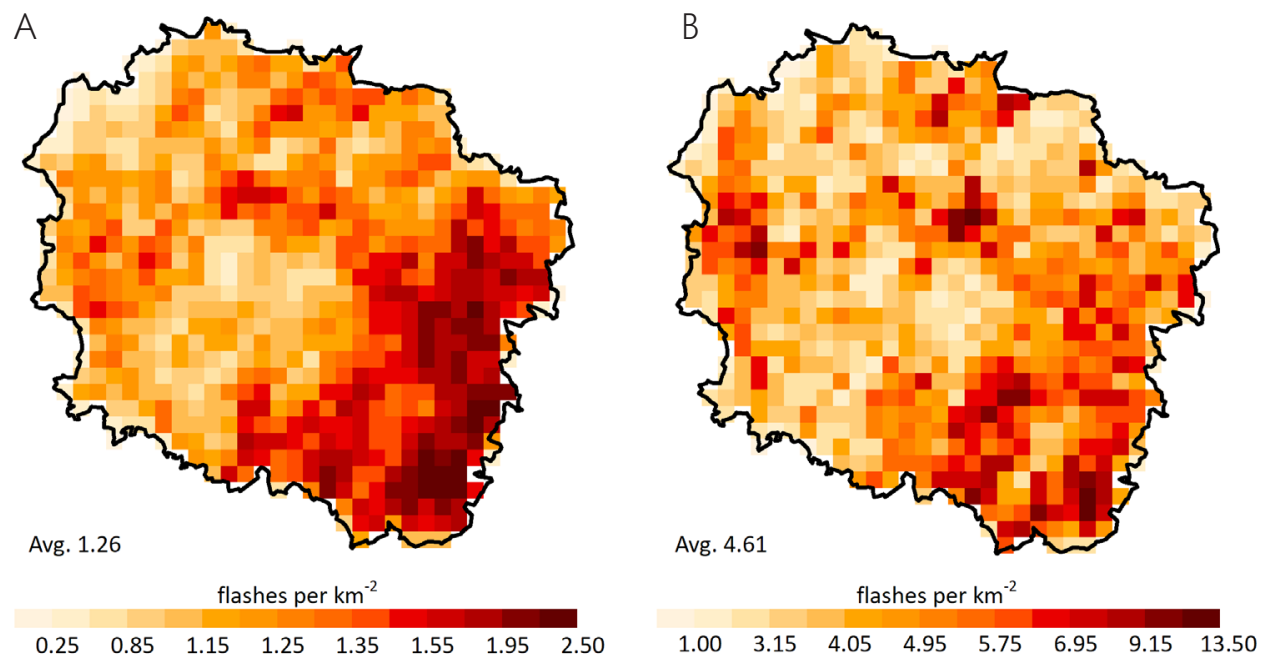

Figure 4. Number of CG flashes $\mathrm{km}^{-2}$ in the Kujawsko-Pomorskie voivodeship during the period 20022019. A - the annual average, B - the daily maximum. Lightning densities are computed for $5 \times 5-\mathrm{km}$ grid cells, based on lightning data from the PERUN network

do throughout the year in other areas. This type of storm is referred to as a "mesoscale convective system" (MCS) (Houze, 2004), which is characterised by high electrical activity due to the strong development of storm cells. Thunderstorms of this type do not occur in Poland very often, but their occurrence determines the spatial distribution of CG flashes. This was the case on, for example August 10 and 11, 2017 (Sulik \& Kejna, 2020).

In each case of the analysed years of this period, a slightly different spatial distribution of discharges is noted in the voivodeship. However, there are clearly more discharges in the east of the voivodeship. The lowest values were recorded in the central part of the study area and in the north-west (a region of forest land). In the spatial distribution for the period 2002-2019 (Fig. 5) it is hard to clearly determine the impact of land cover or its influence on the occurrence of increased discharges. However, the dominant direction of movement of storm cells from southwest to north-east is clearly noticeable. This corresponds to the typical movement of air masses in moderate climatic zones (inflow of polar-sea air from the west and tropical air from the south). The prevailing wind direction in Poland is westerly, so in central Poland there are sometimes conditions favourable to the formation of storms and movement to the north-east, often taking well-developed (mature stage) forms of Cumulonimbus cloud already in the province. In this case, various forms of spatial differentiation in terms of storm activity are visible. The occurrence of far calmer years is associated with a much cooler summer in months characterised as months in which severe weather phenomena occur. The marked eastern corridor of passing storms in the Kujawsko-Pomorskie voivodeship seems to be disappearing or even inactive in 2013. Most of the storms in that year were concentrated in the central part of the analysed area. Undoubtedly, the strongest storm incident occurred over two special days in August 2017 when, during one day, a storm supercell generated a significant number of discharges exceeding the total number of recorded discharges for one year. Therefore, August 2017 was the year with the largest number of atmospheric discharges recorded in the Kujawsko-Pomorskie voivodeship since the beginning 


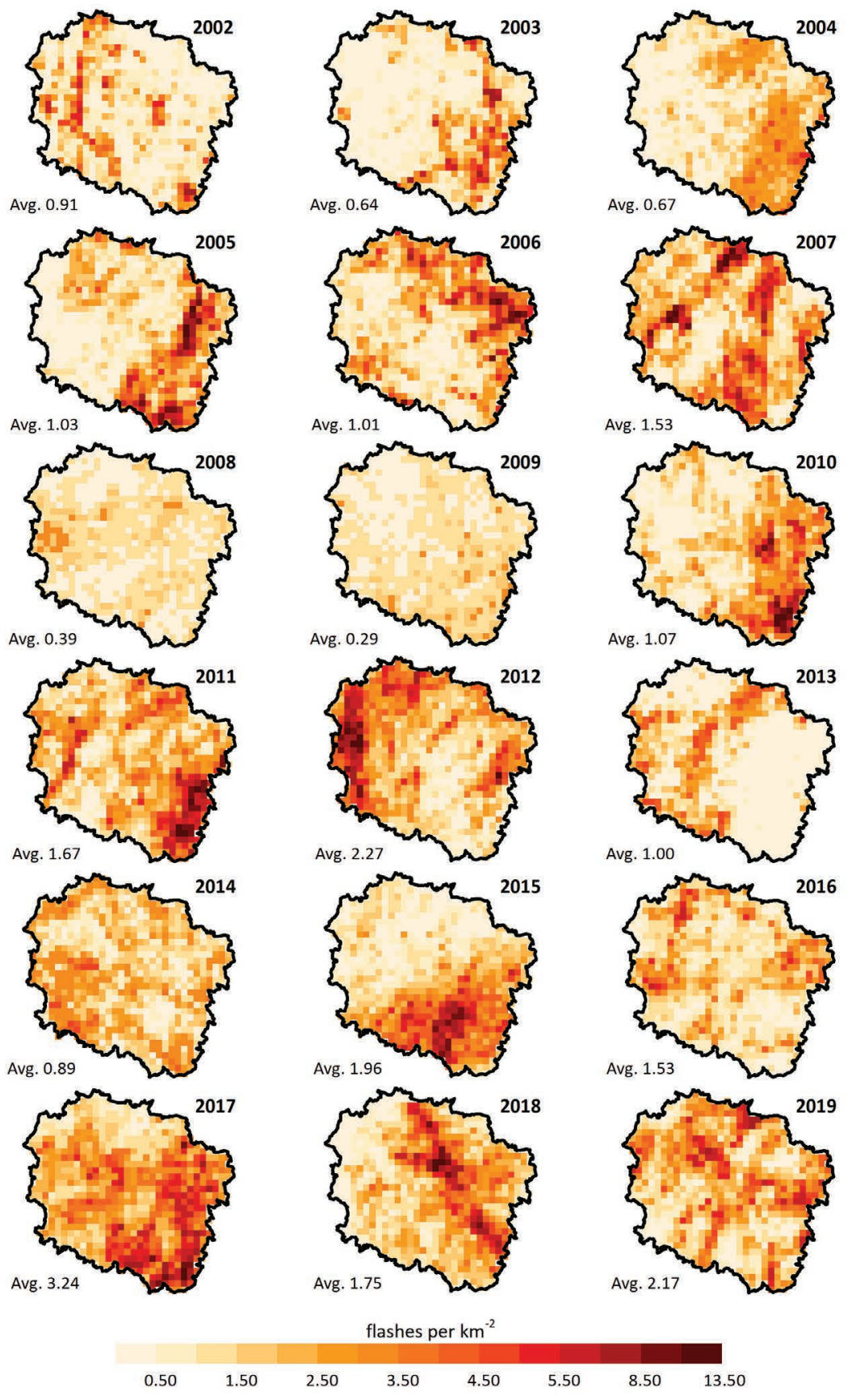

Figure 5. Annual number of CG flashes $\mathrm{km}^{-2}$ in the Kujawsko-Pomorskie voivodeship during the period 2002-2019, based on lightning data from the PERUN network 
of the PERUN detection system. There were 58,288 discharges detected at that time, of which 44,823 were on August 10 and 11 (Sulik \& Kejna, 2020).

\section{The impact of rivers and cities on lightning flash density}

Local topographic conditions can significantly affect the movement of storm cells and the spatial distribution of lightning. Storm activity is much more diverse in mountain areas than at the seaside (Bielec-Bqkowska, 2013; Taszarek et al., 2015). In the lowlands, therefore, high-temperature land surfaces and much cooler areas of forests or vast rivers and lakes have a great impact on the formation of storm clouds.

The main axis of the Kujawsko-Pomorskie voivodeship is the Poland's largest river, namely the Vistula. In the studied area, the river flows for a distance of about $300 \mathrm{~km}$. On this section, the Vistula riverbed is 0.3$1.0 \mathrm{~km}$ wide. An artificial reservoir on the Vistula in the vicinity of Włocławek is the only larger open water body (average $1.5 \mathrm{~km}$ wide). To determine how the occurrence of lightning depends on the Vistula River in the voivodeship, a strip (buffer) was designated at a distance of $10 \mathrm{~km}$ from the river, containing 10 separate sub-buffers of about $1 \mathrm{~km}$ wide. The entire 18 years of PERUN system measurements were calculated in grids of $0.5 \times 0.5 \mathrm{~km}$ so as to render and present the spatial differentiation of discharges as precisely as possible.

The general spatial distribution of CG discharges in the Vistula region is quite diverse. In the whole $10 \mathrm{~km}$ buffer area, about 95,165 CG flashes were detected (Fig. 6). A significantly smaller number of CG flashes were found in the grids through which the river flows (2758 flashes), while in the belt $1-2 \mathrm{~km}$ from the river there were 9017. When analysing the values in the remaining buffers further from the Vistula River, a slight increase in discharges can be observed, sustained in the range above 9000 flashes. Therefore, it is confirmed that the river's influence on the number of CG flashes is only marked in its immediate vicinity. The cooler water in the summer season has a lower convective potential for the development of storm clouds.

The general spatial distribution of discharges is also confirmed for urban areas (Fig. 6). Urban areas are characterised by a diversified structure of land use. There is dense development and there are anthropogenically transformed areas. In urbanised areas, an urban heat island is created (e.g. in Toruń it reaches $1{ }^{\circ} \mathrm{C}$ - Przybylak et al., 2017). Atmospheric instability increases above the hot areas, which favours the development of convection clouds. The discharges generated from the Cumulonimbus cloud are initiated by high objects located in cities. The average values of annual CG discharges increase in a south-eastwards direction with the values of 7.2 discharges in Grudziądz to 12.5 in Włocławek. However, when analysing the distribution of the CG discharges, no regularity was found (Fig. 6).

\section{Annual course of CG lightning flash density}

The previously mentioned climatological studies on the electrical activity of storms in Poland were examined by Taszarek et al. (2015). Those authors said that the most storm activity was in the warm half of the year, with a maximum in July.

The analysis carried out in this study proves that the storm season in the voivodeship begins in April, especially in its second half, and lasts until September. July is the month with the most electrical storm activity. The months from May to the end of August are characterised by a significant number of hot or very hot days. In summer, thunderstorms often occur on the atmospheric fronts, when cooler polar-sea air displaces hot tropical air. In June, storm trails are visible in the centralwestern part of the region (Fig. 7). In July and August, the maximum electrical activity of storms occurred in the eastern part of the province. 

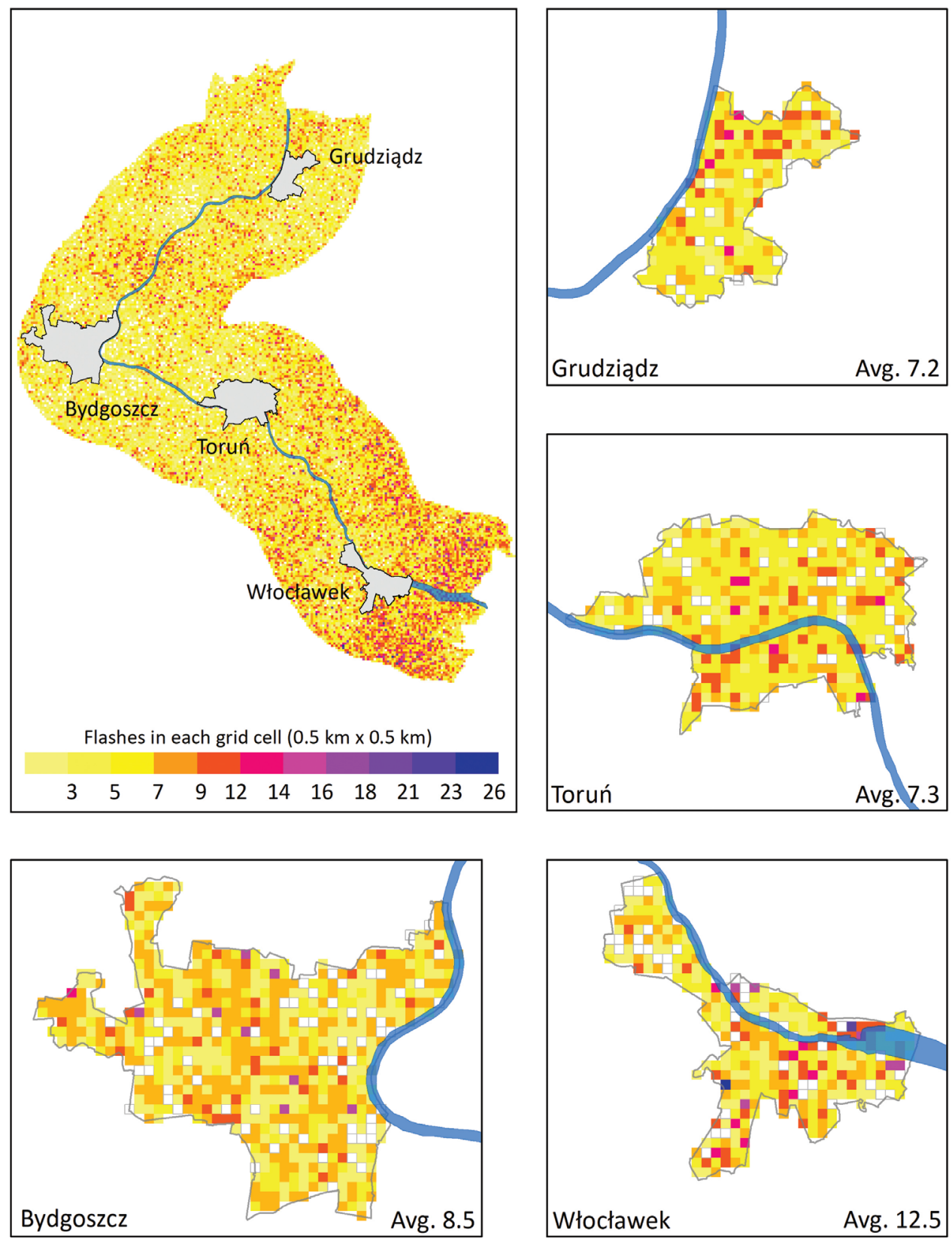

Flashes in each grid cell $(0.5 \mathrm{~km} \times 0.5 \mathrm{~km})$

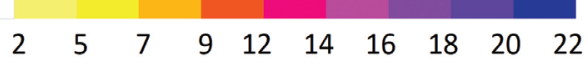

Figure 6. Annual number of CG lightning flashes computed in $0.5 \times 0.5-\mathrm{km}$ grid cells, 2002-2019. Spatial diversity computed in $0.5 \times 0.5-\mathrm{km}$ grid cells for Vistula riverbed with $18-\mathrm{km}$ buffer. Based on lightning data derived from the PERUN network 

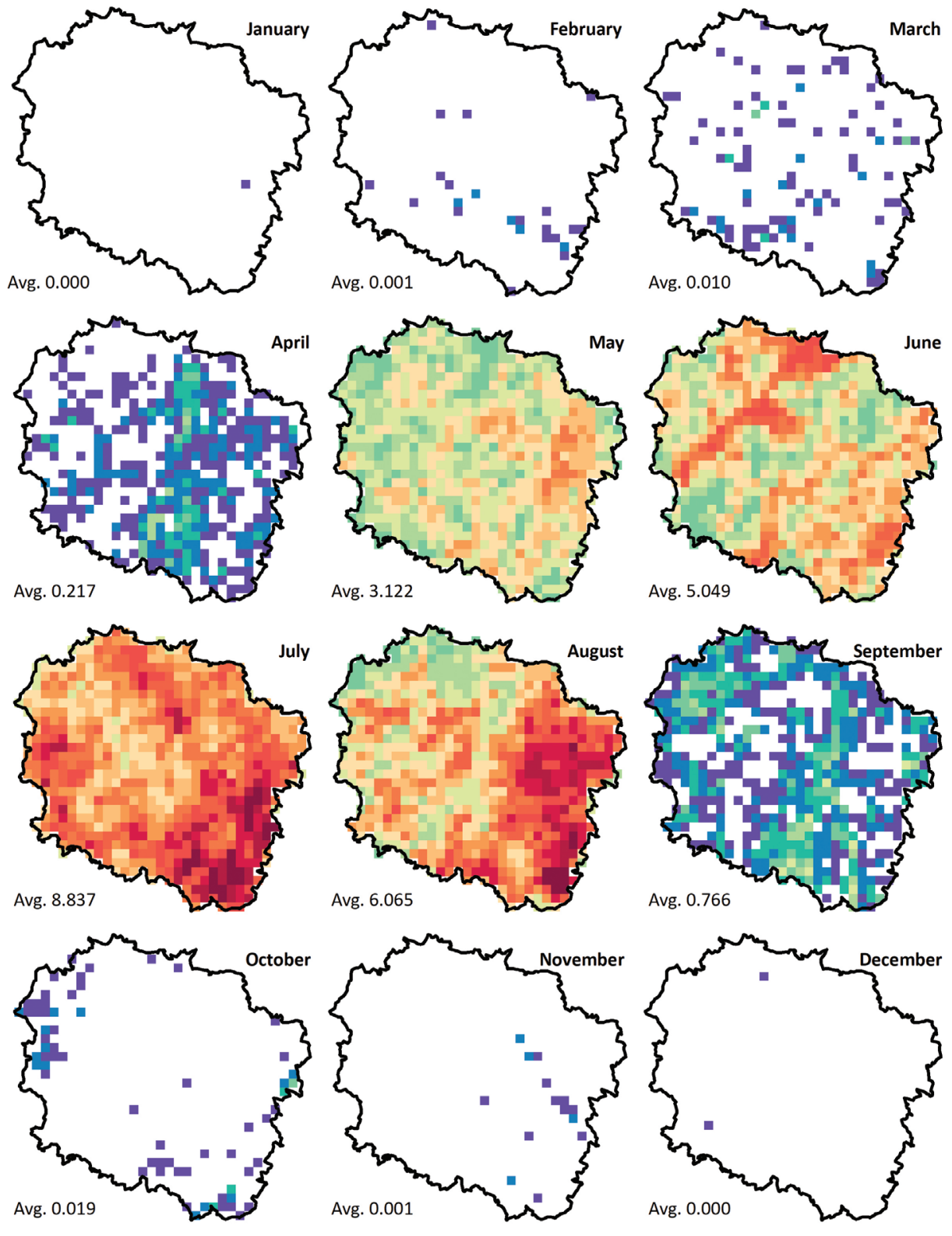

flashes per $\mathrm{km}^{-2}$

$$
\begin{array}{lllllllllllllll}
0.5 & 1.0 & 2.0 & 3.0 & 4.0 & 5.0 & 6.0 & 7.0 & 8.0 & 9.0 & 10.0 & 11.0 & 13.0 & 14.0 & 16.5
\end{array}
$$

Figure 7. Average monthly number of CG flashes $\mathrm{km}^{-2}$ in the Kujawsko-Pomorskie voivodeship during the period 2002-2019, based on lightning data from the PERUN network 
In some years, there were months with increased electrical storm activity. The aforementioned case of the formation of a supercell storm is not the only one in the history of measurements in the province, though it is the most extreme. Equally strong storm incidents in one month are evidenced by data from July 2012, where the detection system detected 31,699 discharges. Similarly, on August 10, 2017, the powerful MCS system generated more than 20,000 ground discharges in one hour in the abovementioned area (Sulik \& Kejna, 2020).

\section{Daily course of CG lightning flashes}

Time of day is also important in forming storms and electrical phenomena. In many regions of the world there is a tendency for them to increase in frequency in the afternoon, when daily air temperatures are the highest (Kotroni \& Lagouvardos, 2016). This research analyses the daily course of storm incidence and atmospheric discharges in individual months (Fig. 8). In the period 2002-19, storms occurred most often between 14:00 and 18:00. However, thunderstorms are possible at other times of the day. They are most often associated with storms of frontal genesis.

In January and February, due to the lack of conditions favourable to the formation of storms, discharges practically do not occur, and if they are recorded by the detection system, this usually happens between 11:00 and 18:00. March is a month in which storms are also few and the number of discharges is negligible, reaching a maximum of 3.8 discharges from 12:00 to 13:00. The storm season in Poland begins in April, and especially in its second, much warmer half. In the surveyed period, in April, on average, there were even 50 discharges recorded in the warmest period of the day from 13:00 to $16: 00$. Intensive influx of solar radiation, ground heating and much higher temperatures during the day determine the significant activity of storms in the afternoon. In May, the peak of electrical activity occurs from 16:00 to 18:00. In June, apart from the intensification of discharges in the afternoon, there was a second maximum in the morning. This is related to atmospheric fronts, on which complex multicellular clusters are often created that generate an increased number of lightning discharges, hence recorded average values exceeding 300 discharges. In July and August there is the largest number of storms and the lightning strikes they generate. According to research by Bielec (2000), storms can occur at any time during this period, but as in the case of other months, their peak falls between 11:00 and 18:00. The tendency for maximum storm activity in the afternoon is confirmed during this period (Fig. 8C). The autumn months are the period during which storm activity gradually disappears. However, not infrequently, especially in the years 2017-19, in the early days of October, residual air of tropical origin increases the formation of Cumulonimbus clouds generating single lightning strikes. Such a process is also determined by the advancement of air masses from the west and the movement of fronts on which storms form. On average, at the peak time of 13:00 to 14:00 there were only 7 discharges in October, which means that the storm season is over. Storm activity is negligible in November and December (Fig. 8D) and, in the daily course, the maximum number of storms and lightning occurs in the afternoon.

\section{Trends and patterns}

It can be assumed that progressive climate change will contribute to extending the duration of the storm season and, consequently, storm activity (Taszarek et al., 2015). In the Kujawsko-Pomorskie voivodeship there is a significant variation in the number of days with a storm in individual years. There is a clearly visible upward trend in the number of days (0.82 days year ${ }^{-1}$ ) (Fig. 9B). According to the adopted methodology, the fewest storm days occurred in 2003 (25 storm days). The highest number of thunderstorm days was in 2014 (65 days). 

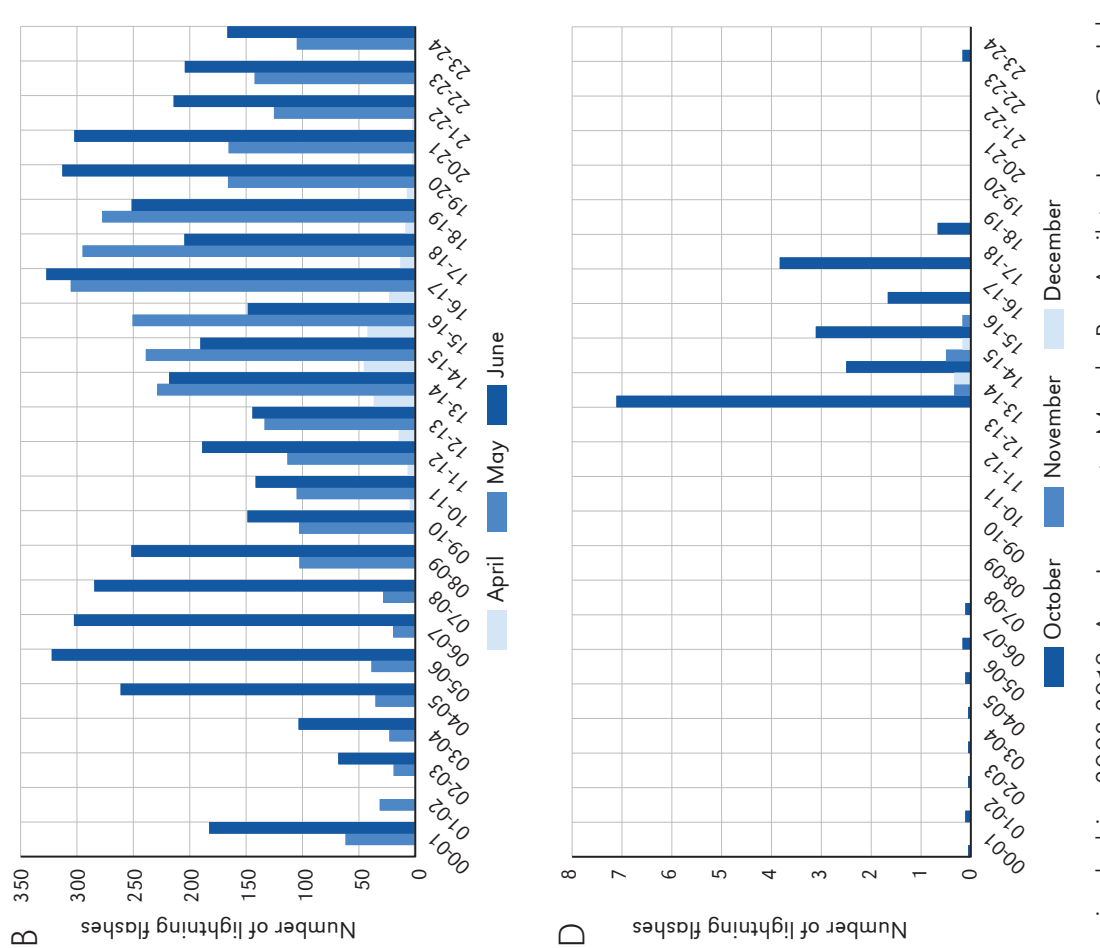

$\frac{\lambda}{3}$

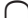

$\cup$

$\stackrel{\oplus}{5}$

$\frac{1}{ \pm}$

$\infty$

는

$$
\Sigma
$$

คำ

வे
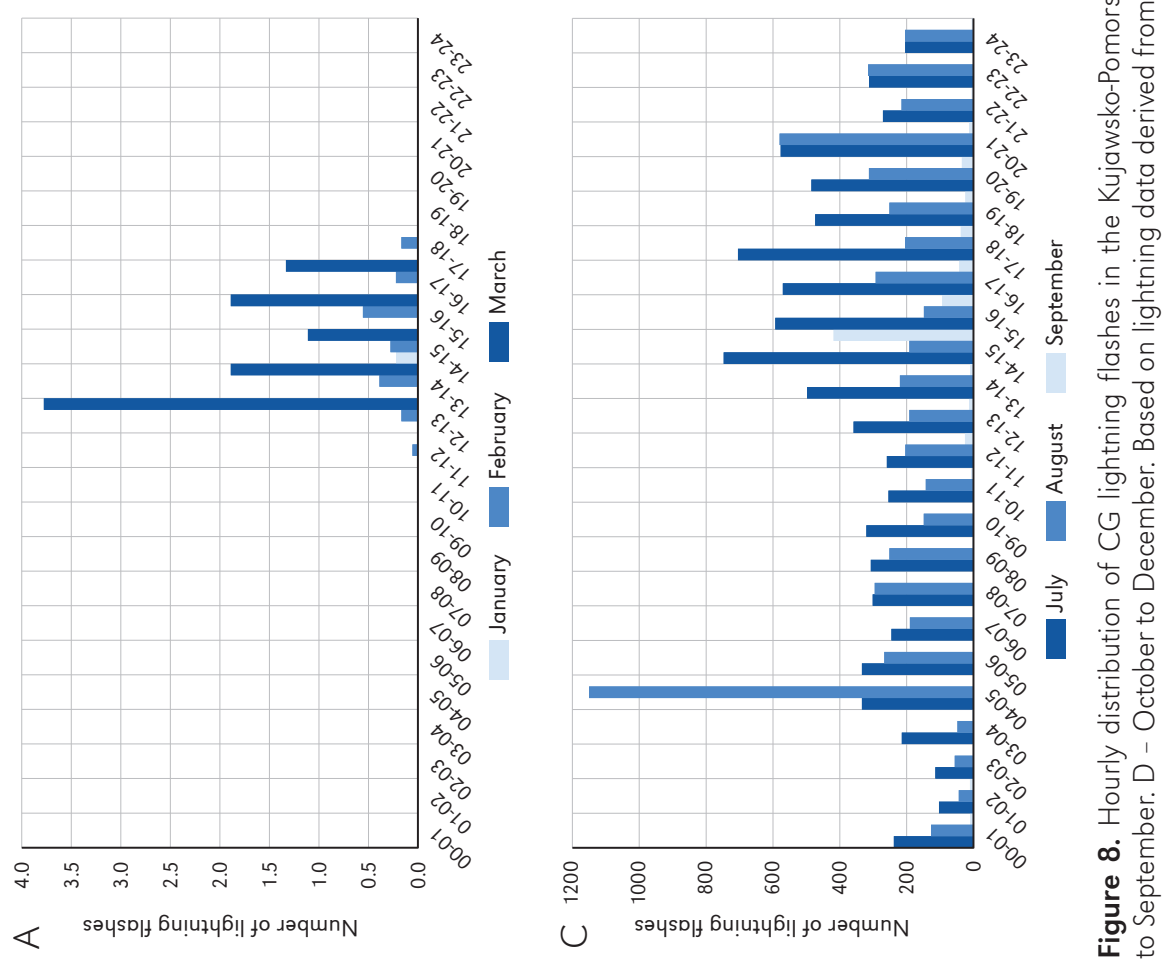

$\frac{\infty}{\square} \stackrel{\oplus}{ \pm}$

क⿺ 

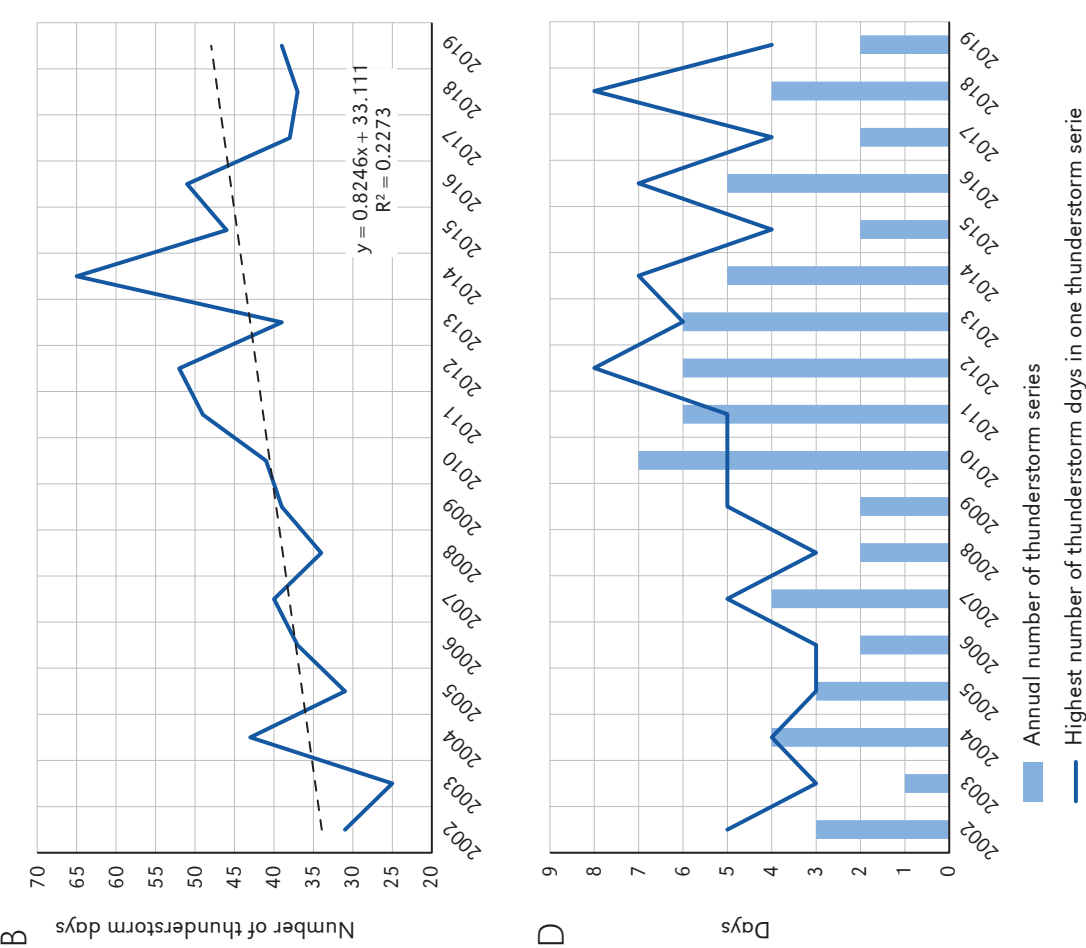

这

है

$\stackrel{\varepsilon}{\frac{\varepsilon}{\supset}}$

$\overline{\mathrm{o}}$ 을

哀

$\cup \stackrel{0}{+}$

vं

응 이

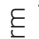

总. 드

응 둥

క
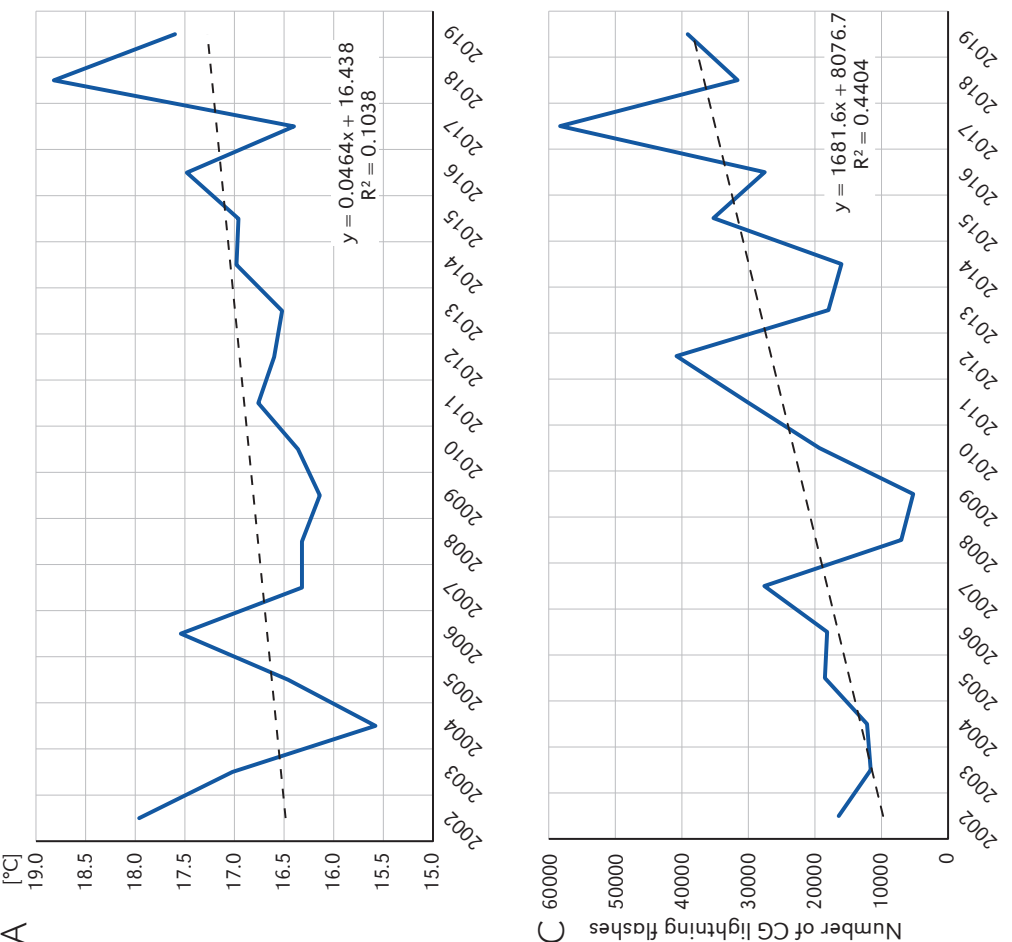

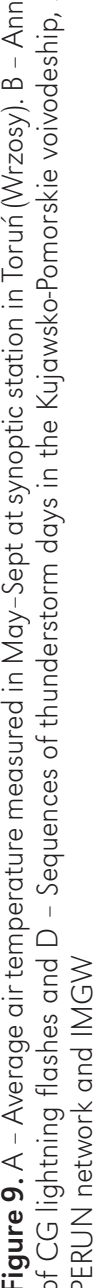


Throughout the period considered, years with great storm activity are separated by calmer years. The number of three-day storm series is also increasing. In the analysed period, two strings of eight days in a row with a storm were found (Fig. 9D).

In the voivodeship in the analysed period frequency of discharges is clearly growing, by 1681 discharges year ${ }^{-1}$ (Fig. 9C). This trend is disturbed for years with increased storm activity, which appear every few years, separated by calmer years. Their annual total increased from approx. 15,000 up to 27,614 discharges detected in 2007. In the years 2008-09 there was a clear decrease in storm activity: these were the years with the lowest discharge values during the 18 years of research. Since 2009, the number of discharges has increased, up to 40,795 in 2012. In subsequent years there were fluctuations in the number of discharges from the maximum in 2017 (58,228 discharges). However, it should be noted that this large number of discharges was affected especially by two days (10 and 11 August). In these days there were very intense MCS systems (Taszarek et al., 2019; Sulik $\&$ Kejna, 2020). The increasing number of lightning discharges indicates the growing potential energy of the atmosphere. Record values occurred in 2007, 2012 and 2017, when storm systems in the form of MCS and training storms occurred.

There has been an upward trend in the number of discharges in individual months. It was also found that the storm season begins sooner than in previous years and lasts longer. In recent years, storms have the potential to create dangerous phenomena, such as the example of August 11, 2017.

\section{Summary and final remarks}

The main purpose of the study was to examine the spatial diversity of cloud-to-ground (CG) lightning flashes in the Kujawsko-Pomorskie voivodeship (Poland) in the years 2002-2019 , to determine the daily, monthly and annual course, and to calculate the number ofthunderstorm daysalong withtrends. Tocarry out this study, data on CG flashes from the Polish lightning detection system PERUN were used.

Based on the analysis of CG discharges, it has been shown that in the Kujawsko-Pomorskie voivodeship the number of days with a storm ranges from 27 to 41 . These are higher values than those given in previous studies, in which approx. 23 days with a storm were given annually in the voivodeship (Lorenc, 2005; Bielec-Bakowska, 2013). This difference results from the fact that observations made by observers at meteorological stations do not take into account all discharges. Some discharges were not noticed by observers.

In the years 2002-2019 in the Kujawsko-Pomorskie voivodeship 432,926 CG flashes were detected, which gives an average annual value of about 24,051 discharges. On average, 2.5 lightning strikes $\mathrm{km}^{-2} \cdot \mathrm{yr}^{-1}$ occurred in areas of maximum discharge. This is comparable to the results obtained by Taszarek et al. (2015), who stated that in the years 2002-13 the maximum in Poland occurred in Mazovia (2.7 flashes $\mathrm{km}^{-2} \cdot \mathrm{yr}^{-1}$ ). These values are much lower than in southern Europe, e.g. in Italy 5 CG flashes $\mathrm{km}^{-2} \cdot \mathrm{yr}^{-1}$ (Taszarek et al., 2019). In terms of spatial differentiation of ground discharges, each year was slightly different, but the south-eastern part of the voivodeship is clearly marked by an increased number and frequency of discharges. This area has also been designated by Taszarek et al. (2015) as part of the main storm trail in Poland. In that study, the authors found as many as 4,328,892 discharges throughout the entire period (2002-13), with an average of 151 days of storm each year throughout the country. The number of days with a storm was also confirmed to increase in a south-eastwards direction from the Baltic Sea, which would agree with the distribution of days with the storm in the Kujawsko-Pomorskie voivodeship. Areas with fewer discharges include, among others, the north-western or central part of the research area, where there are extensive 
forest complexes. The analysis showed the influence of the Vistula River on the distribution of atmospheric discharges. Their number are small in the grids through which the Vistula flows and grows with distance from the river. In the largest cities, the distribution of discharges is random.

The work also analysed the variability of storms and lightning in the seasonal cycle. In Poland, the storm season usually lasts from May to August, with July being the month with the highest frequency of storms. This was also confirmed for the area of the voivodeship: in July each year, there are an average of 8830 discharges in the region, whereas in winter months (Dec-Feb) CG flashes average five per year. Thunderstorms during this period are rare, but they cannot be completely ruled out, especially since increasingly often there is no cold winter in the Polish climate, which leads to an increase in air instability also in the winter months. Over the course of the day, most of the recorded storms occur in the daytime, with a maximum around $14: 00$ to $18: 00$, and with average values of about 1500 discharges, and a minimum around 07:00, when air instability is at a minimum.

In recent years we have been observing disturbing changes taking place in nature: prolonged drought, rising air temperature, intensification of extreme weather phenomena. Rising air temperature, which causes the surface of the seas and oceans to heat up, also affects the activity of storms, which is confirmed by Kotroni and Lagouvardos (2016) in their study using data from the ZEUS system. Under conditions of rising global air temperature, which also pertain to Poland (Wibig, 2017) it has been hypothesised extreme weather phenomena are increasing in frequency and intensity. The temperature during the storm season, which in Poland falls from May to September, is of particular importance. This paper analyses the variability and trend of days with storm and lightning discharges in the Kujawsko-Pomorskie voivodeship in the years 2002-19. The number of thunderstorm days also shows an increasing trend (0.82 days year $\left.{ }^{-1}\right)$. Older climatological studies on the subject of storms in Poland proved that for many years the increase in the number of days with a storm could not be confirmed based on synoptic observations (Bielec, 1998). The number of CG flashes was found to increase at a rate of 1681 discharges per year. This trend is related to the increase in air temperature in the storm season (AprSept) reaching $\left(0.04^{\circ} \mathrm{C}\right.$ year $\left.{ }^{-1}\right)$. Sequences of days with a storm occur more frequently.

The latest research confirms the increase in dangerous atmospheric phenomena in Europe. However, there are places where a downward trend can be noted. The changes are fastest in northern Europe and slowest in southern areas (Taszarek et al., 2020). In the area of central Europe, there is an increase in storm activity in July and August. As for the increase in the number of days with a storm, such changes took place in the area of the Alps, central and south-eastern Europe, in the form of 5-10 days with a storm per year. The probability of severe thunderstorm days also increases from year to year (Taszarek et al., 2019). Further research into this topic is necessary, especially concerning the atmospheric conditions during the days with the most intense thunderstorms.

Editors' note:

Unless otherwise stated, the sources of tables and figures are the authors', on the basis of their own research. 


\section{References}

Anderson, G., Klugmann, D. (2014). A European lightning density analysis using 5 years of ATDnet data. Natural Hazards and Earth System Sciences, 14(4), 815-829. https://doi.org/10.5194/nhess-14-815-2014

Bielec, Z. (2000). Przebieg dobowy i charakterystyka synoptyczna burz w Krakowie w latach 1896-1995. Kraków: Uniwersytet Jagielloński.

Bielec, Z. (1998). Long-term variability of the thunderstorm frequency in Szczecin, Łódź, Kraków and Kasprowy Wierch in the period 1954-1993. Acta Universitatis Lodziensis, Folia Geographica Physica, 3, 449-453.

Bielec-Bąkowska, Z. (2013). Burze i grady w Polsce. Prace Geograficzne, (132), 99-132. https://doi.org/10.4467/20833113PG.13.005.1095

Biron, D. (2009). LAMPINET-Lightning detection in Italy. In H.D. Betz, U. Schumann, P. Laroche (Eds.), Lightning: Principles, instruments and applications review of modern lightning research (pp. 141-159). Dordrecht: Springer. https://doi.org/10.1007/978-1-4020-9079-0_6

Bodzak, P. (2006). Detekcja i lokalizacja wyładowań atmosferycznych. Warszawa: Instytut Meteorologii i Gospodarki Wodnej.

CORINE Land Cover. (2018). https://land.copernicus.eu/pan-european/corine-land-cover/clc2018

Czernecki, B., Taszarek, M., Kolendowicz, L., Konarski, J. (2016). Relationship between human observations of thunderstorms and PERUN lightning detection network in Poland. Atmospheric Research, 167, 118-128. https://doi.org/10.1016/j.atmosres.2015.08.003

Diendorfer, G. (2008). Some comments on the achievable accuracy of local ground flash density values. In 29th International Conference on Lightning Protection (pp. 2-8-1-2-8-6). Uppsala, Sweden: ICLP Centre.

Enno, S.E. (2011). A climatology of cloud-to-ground lightning over Estonia, 2005-2009. Atmospheric Research, 100, 310-317. https://doi.org/10.1016/j.atmosres.2010.08.024

Główny Urzad Statystyczny (Statistics Poland), https://www.stat.gov.pl/

Houze Jr, R.A. (2004). Mesoscale convective systems. Reviews of Geophysics, 42(4), RG4003. https://doi.org/10.1029/2004RG000150

Kolendowicz, L. (1996). Burze na obszarze Polski Północno-Zachodniej w świetle częstości występowania różnych typów cyrkulacji atmosfery. Zeszyty IGiPZ PAN, 39, 1-115.

Kolendowicz, L. (2006). The influence of synoptic situations on the occurrence of days with thunderstorms during a year in the territory of Poland. International Journal of Climatology, 26(13), 1803-1820. https://doi.org/10.1002/joc.1348

Kotroni, V., Lagouvardos, K. (2016). Lightning in the Mediterranean and its relation with sea-surface temperature. Environmental Research Letters, 11, 034006. https://doi.org/10.1088/1748-9326/11/3/034006

Lorenc, H. (2005). Atlas klimatu Polski. Warszawa: Instytut Meteorologii i Gospodarki Wodnej.

Mäkelä, A., Rossi, P., Schultz, D.M. (2011). The daily cloud-to-ground lightning flash density in the contiguous United States and Finland. Monthly Weather Review, 139, 1323-1337.

https://doi.org/10.1175/2010MWR3517.1

Novák, P., Kyznarová, H. (2011). Climatology of lightning in the Czech Republic. Atmospheric Research, 100(4), 318-333. https://doi.org/10.1016/j.atmosres.2010.08.022

Pohjola, H., Mäkelä, A. (2013). The comparison of GLD360 and EUCLID lightning location systems in Europe. Atmospheric Research, 123, 117-128, https://doi.org/10.1016/j.atmosres.2012.10.019

Przybylak, R., Uscka-Kowalkowska, J., Araźny, A., Kejna, M., Kunz, M., Maszewski, R. (2017). Spatial distribution of air temperature in Torun (Central Poland) and its causes. Theoretical and Applied Climatology, 127(1), 441-463. https://doi.org/10.1007/s00704-015-1644-2 
Santos, J.A., Reis, M.A., Sousa, J., Leite, S.M., Correia, S., Janeira, M., Fragoso, M. (2012). Cloud-to-ground lightning in Portugal: Patterns and dynamical forcing. Natural Hazards and Earth System Sciences, 12(3), 639-649. https://doi.org/10.5194/nhess-12-639-2012

Schulz, W., Cummins, K., Diendorfer, G., Dorninger, M. (2005). Cloud-to-ground lightning in Austria: A 10-year study using data from a lightning location system. Journal of Geophysical Research: Atmospheres, 110(D9). https://doi.org/10.1029/2004JD005332

Soriano, L.R., De Pablo, F., Tomas, C. (2005). Ten-year study of cloud-to ground lightning activity in the Iberian Peninsula. Journal of Atmospheric and Solar-Terrestrial Physics, 67(16), 1632-1639. https://doi.org/10.1016/j.jastp.2005.08.019

Sulik, S., Kejna, M. (2020). The origin and course of severe thunderstorm outbreaks in Poland on 10 and 11 August 2017. Bulletin of Geography: Physical Geography Series, 18(1), 25-39. https://doi.org/10.2478/bgeo-2020-0003

Taszarek, M., Czernecki, B., Kozioł, A. (2015). A cloud-to-ground lightning climatology for Poland. Monthly Weather Review, 143, 4285-4304. https://doi.org/10.1175/MWR-D-15-0206.1

Taszarek, M., Allen, J., Púčik, T., Groenemeijer, P., Czernecki, B., Kolendowicz, L., Lagouvardos, K., Kotroni, V., Schulz, W. (2019). A climatology of thunderstorms across Europe from a synthesis of multiple data sources. Journal of Climate, 32(6), 1813-1837. https://doi.org/10.1175/JCLI-D-18-0372.1

Taszarek, M., Pilguj, N., Orlikowski, J., Surowiecki, A., Walczakiewicz, S., Pilorz, W., Piasecki, K., Pajurek, Ł., Półrolniczak, M. (2019). Derecho evolving from a mesocyclone - A study of 11 August 2017 severe weather outbreak in Poland: Event analysis and high-resolution simulation, Monthly Weather Review, 147(6), 2283-2306, https://doi.org/10.1175/MWR-D-18-0330.1

Taszarek, M., Kendzierski, S., Pilguj, N. (2020). Hazardous weather affecting European airports: Climatological estimates of situations with limited visibility, thunderstorm, low-level wind shear and snowfall form ERA5. Weather and Climate Extremes, 28, 100243. https://doi.org/10.1016/j.wace.2020.100243

Wapler, K. (2013). High-resolution climatology of lightning characteristics within Central Europe. Meteorology and Atmospheric Physics, 122, 175-184. https://doi.org/10.1007/s00703-013-0285-1

Wibig, J. (2017). Heat waves in Poland in the period 1951-2015: Trends, patterns and driving factors. Meteorology Hydrology and Water Management Research and Operational Applications, 6(1), 37-45. https://doi.org/10.26491/mhwm/78420

Wu, F., Cui, X., Zhang, D.L., Liu, D., Zheng, D. (2016). SAFIR-3000 lightning statistics over the Beijing Metropolitan Region during 2005-07. Journal of Applied Meteorology and Climatology, 55(12), 2613-2633. https://doi.org/10.1175/JAMC-D-16-0030.1 
